\title{
Genetic variability for morphology, growth and forage yield among perennial diploid and tetraploid lucerne populations (Medicago sativa L)
}

\author{
B Julier *, A Porcheron, C Ecalle, P Guy \\ INRA, station d'amélioration des plantes fourragères, F86600 Lusignan, France
}

(Received 31 March 1995; accepted 10 July 1995)

\begin{abstract}
Summary - The wide diversity within the Medicago sativa complex is well known, but comparative data on different populations representing the sub-species sativa and falcata are lacking. Morphological and agronomic characters of 25 populations or varieties of lucerne belonging to the $M$ sativa complex were studied at Lusignan (France) in 1993 and 1994. The landraces and varieties of the sub-species sativa were clearly different from the wild populations of the 2 sub-species sativa and falcata by their erect growth habit, their fast regrowth after cutting, the absence of rhizomatous plants, their tall height and their high forage yield. Within the cultivated populations, those originating from northern France had a higher winter resistance than the Mediterranean populations, and higher yields. The winter resistance trait and the variegated flowers of the French sativa landraces show that they have integrated some traits belonging to sub-species falcata. The group of wild populations contained diploid and tetraploid populations, and sativa or falcata populations. Among the characters analysed, only flower colour made the distinction possible between the wild sativa populations from Spain (Mielga) with purple flowers and the falcata populations with yellow flowers. This convergence of forms between the 2 sub-species could be a strategy of tolerance to animal feeding and to treading.
\end{abstract}

Medicago sativa $\mathrm{L}$ = lucerne / population / morphology / agronomic trait / genetic variability

Résumé - Variabilité génétique pour la morphologie, la croissance et le rendement en matière sèche chez la luzerne pérenne diploïde et tétraploïde (Medicago sativa L). La grande diversité du complexe Medicago sativa est bien connue, mais des données comparatives de différentes populations représentant les sous-espèces sativa et falcata manquent. Les caractéristiques morphologiques et agronomiques de 25 populations ou variétés de luzerne appartenant au complexe M sativa ont été étudiées à Lusignan (France) en 1993 et 1994. Les populations et variétés cultivées de la sous-espèce sativa se distinguent nettement des populations sauvages des 2 sous-espèces sativa et falcata par leur port dressé, leur repousse rapide après une coupe, leur hauteur élevée et leur fort rendement. Parmi les populations cultivées, celles originaires du nord de la France ont une résistance à l'hiver supérieure aux méditerranéennes, ainsi qu'un meilleur rendement. Par leurs caractères de résistance à l'hiver et leurs fleurs bigarrées, ces populations sativa françaises montrent qu'elles ont intégré certains caractères provenant de la ssp falcata. Le groupe des populations sauvages comprend à la fois des populations diploïdes et tétraploïdes, falcata ou sativa. Pour les caractères analysés, seule la couleur des fleurs permet de distinguer les populations sauvages sativa d'Espagne (Mielga) à fleurs violettes des populations falcata à fleurs jaunes. La convergence de forme de ces 2 sous-espèces pourrait représenter une stratégie de tolérance au pâturage.

\section{Medicago sativa $L$ = luzerne / population / morphologie / caractère agronomique / variabilité génétique}

\footnotetext{
${ }^{*}$ Correspondence and reprints
} 


\section{INTRODUCTION}

Perennial lucerne (Medicago sativa $L$ ) exists as a cultivated but also as a wild species. A large genetic variability is available within this species. Several authors have debated about taxonomic classification (Lesins and Lesins, 1979; Sinskaya, 1950, cited by Lesins and Lesins, 1979; Quiros and Bauchan, 1988). Quiros and Bauchan (1988) consider that the $M$ sativa complex contains 2 main sub-species and 1 less widespread sub-species:

(1) Subspecies sativa, to which belong most of the cultivated varieties or landraces, is characterised by purple flowers, a tap root, an erect growth habit, coiled pods, a poor winter hardiness and no dormancy. The geographical origin of this sub-species is located in the Middle-East, and the zone of diversification is the Mediterranean area.

(2) Sub-species falcata is mainly wild, with yellow flowers, a prostate growth habit, fasciculate roots, sickle-shaped pods, strong winter hardiness and winter dormancy. It originates from Central Asia, and is diversified in northern Eurasia.

(3) Sub-species glutinosa, with yellow flowers, coiled and glandular-haired pods. It originates from Caucasia but is not widespread elsewhere.

Within each of these sub-species, genetic evolution occurred, which was mainly driven by 2 processes. Firstly, geographical diversification of lucerne was achieved by an adaptation to climate, soils or pests. Secondly, man has bred lucerne for its use and modified agronomically important traits. Furthermore, in Europe, both sub-species coexist and crosses have occurred for ages (Lesins and Lesins, 1979). In both ssp sativa and falcata, diploid and tetraploid forms exist; the tetraploids are usually more vigorous than diploids (Dunbier et al, 1975; Volenec, 1988) and are more frequently used by man for cultivation. The diploid form of sativa is called coerulea, and the diploid form of falcata is called falcata, romanica or quasifalcata. In Spain, wild forms of the ssp sativa, called Mielga, exist and are characterised by a prostate growth habit but purple flowers. In that country, lucerne was first introduced in Roman times (Bolton et al, 1972), and Mielga probably originated from these populations (Delgado Enguita, 1989). The cultivated Spanish populations were then introduced during the Moorish invasions in the 8th century (Hidalgo Maynar, 1966).

Another species related to the $M$ sativa complex is M glomerata (Quiros and Bauchan, 1988).
This originates from the Mediterranean Alps or North Africa and is intermediate between ssp sativa and ssp falcata because of its coiled pods and yellow flowers.

All the available populations (varieties, landraces or wild populations) can have specific features of interest for breeding, such as characters for adaptation, resistance to pests or stresses, and agronomic value. This study presents an evaluation of the genetic diversity among perennial Medicago for morphological, agronomic and growth traits. The relationships between the various populations and sub-species were investigated. A further paper will deal with characters of forage quality (digestibility), disease and nematode resistance and saponin countent.

\section{MATERIAL AND METHODS}

Twenty-five populations were studied, as described in table I. In the ssp sativa, 5 French landraces and varieties, 3 populations from Morocco (Birouk and Guy, 1986; Birouk et al, 1989), 2 landraces from Tunisia, 4 Spanish landraces and 3 Spanish wild Mielga, and 1 diploid coerulea population were chosen. In the ssp falcata, a Canadian diploid variety, 2 French wild tetraploid populations, an Ukrainian tetraploid population, and 2 Russian diploid populations called by their synonymous romanica and quasifalcata were studied. A glomerata population was included.

In 1992, 15 populations (Villanueva de Jara, Monte Oscuro, Pancrudo, coerulea, Flamande, Provence, Marais de Luçon, Europe, Maktar, romanica, quasifalcata, Anik, Maron, Krasnokutskaya, glomerata) were planted in the nursery (1 block, 30-50 plants per population, $70 \mathrm{~cm}$ between plants) at Station d'amélioration des plantes fourragères INRA (Lusignan, France). In 1993, the following traits were recorded on each plant: rhizomatous plants (plants with lateral expansion of the crown by underground, horizontal stems, as described by Heinrichs in 1963); diameter of the plants at their base in $\mathrm{cm}$ (on 19/03 and 07/08, mean of 2 perpendicular measurements per plant); 8 consecutive measurements of plant height from 19/03 to $27 / 04 / 1993$; 8 consecutive measurements of the length of 1 tagged stem per plant from 16/04 to $16 / 06 / 1993$. Two cuttings were made (on $28 / 06$ and $10 / 08 / 1993$ ) and an average fresh weight per plant was estimated for each cutting.

In 1993, 21 populations (among the 25 populations, only the 4 Spanish landraces were omitted) were planted at INRA (Lusignan, France) in the nursery ( 3 blocks, 19 plants per block, $70 \mathrm{~cm}$ between plants). In September 1993, the individual measurements on each plant were: growth habit (from 1 (prostate) to 5 (erect), stem size (from 1 (thin) to 3 (thick), leaf area (from 1 (small) to 3 (large), inflorescence shape (1 (globular), 2 (moderately elongated), and 3 (elongated). Three scores for regrowth were recorded per 
Table I. Origin of the 25 populations.

\begin{tabular}{|c|c|c|c|c|c|c|c|c|c|}
\hline Name & ubspecies & Country & Region & $\begin{array}{c}\text { Type of } \\
\text { population }\end{array}$ & $\begin{array}{c}\text { Type or } \\
\text { use }\end{array}$ & Ploidy & Longitude & Latitude & $\begin{array}{c}\text { Altitude } \\
(m)\end{array}$ \\
\hline Flamande & sativa & France & North & Landrace & Flemish & $4 x$ & & & \\
\hline Europe & sativa & France & - & Variety & Flemish & $4 x$ & & & \\
\hline Provence & sativa & France & Provence & Landrace & Provence & $4 x$ & & & \\
\hline Marais de Luçon & sativa & France & Vendée & Landrace & Flemish & $4 x$ & & & \\
\hline Magali & sativa & France & - & Variety & Provence & $4 x$ & & & \\
\hline D15 & sativa & Morocco & Draa valley & Landrace & Pre-Saharian oasis & 54 & $30.48 \mathrm{~N}$ & $5.35 \mathrm{~W}$ & - \\
\hline Dem3 & sativa & Morocco & Demnate & Landrace & Valley & $4 x$ & $31.45 \mathrm{~N}$ & $7.06 \mathrm{~W}$ & - \\
\hline Pool 5 & sativa & Morocco & Atlas & Pool & Mountain & $4 x$ & & & \\
\hline Gabès & sativa & Tunisia & - & Landrace & Irrigated oasis & $4 x$ & $32.57 \mathrm{~N}$ & $10.02 E$ & - \\
\hline Maktar & sativa & Tunisia & Maktar & Landrace & - & $4 x$ & - & - & 450 \\
\hline Aragon & sativa & Spain & Cuenca & Landrace & - & $4 x$ & $41.40 \mathrm{~N}$ & $0.50 \mathrm{~W}$ & 250 \\
\hline Mediterraneo & sativa & Spain & Murcia & Landrace & - & $4 x$ & $37.55 \mathrm{~N}$ & $1.15 W$ & 100 \\
\hline Tierra de Campos & sativa & Spain & Palencia & Landrace & - & $4 x$ & $41.35 \mathrm{~N}$ & $4.40 \mathrm{~W}$ & 700 \\
\hline Ampurdan & sativa & Spain & Gerona & Landrace & - & $4 x$ & $42.10 \mathrm{~N}$ & $3.10 \mathrm{E}$ & 70 \\
\hline Villanueva de Jara & sativa & Spain & Cuenca & Wild & Rangeland & $4 x$ & $39.26 \mathrm{~N}$ & $1.58 \mathrm{~W}$ & 730 \\
\hline Monte Oscuro & sativa & Spain & Zaragoza & Wild & - & $4 x$ & $40.45 \mathrm{~N}$ & $1.16 \mathrm{E}$ & 400 \\
\hline Pancrudo & sativa & Spain & Teruel & Wild & - & $4 x$ & $40.46 \mathrm{~N}$ & $1.02 \mathrm{~W}$ & 1100 \\
\hline coerulea & sativa & Russia & Daghestan & Wild & Arid steppes & $2 x$ & $42.00 \mathrm{~N}$ & $47.00 \mathrm{E}$ & - \\
\hline Maron & falcata & France & Lorraine & Wild & - & $4 x$ & $54.00 \mathrm{~N}$ & $4.20 \mathrm{E}$ & 215 \\
\hline Malzeville & falcata & France & Lorraine & Wild & - & $4 x$ & $48.41 \mathrm{~N}$ & $6.31 E$ & 212 \\
\hline Krasnokutskaya & falcata & Ukraine & & Wild & - & $4 x$ & & & \\
\hline Anik & falcata & Canada & Alberta & Variety & - & $2 x$ & & & \\
\hline romanica & falcata & Russia & Krasnodar? & Wild & Arid steppes & $2 x$ & $45.02 \mathrm{~N}$ & $39.00 \mathrm{E}$ & - \\
\hline quasifalcata & falcata & Russia & Krasnodar? & Wild & Meadows & $2 x$ & $45.02 \mathrm{~N}$ & $39.00 \mathrm{E}$ & - \\
\hline glomerata & glomerata & France & Vaucluse & Wild & - & $2 x$ & $43.30 \mathrm{~N}$ & $5.40 \mathrm{E}$ & 450 \\
\hline
\end{tabular}

block (from 1 (weak regrowth) to 5 (strong regrowth), on 28/07, 08/10 and 26/10/1993). In 1994, the following traits were recorded per plant: diameter of the plants (mean of 2 perpendicular measurements, 15/03/1994), 5 measurements of plant height from the 08/04 to 10/05/1994, flower colour (1 (pure purple), 2 (variegated), 3 (pure yellow). The percentage of rhizomatous plants per population, and the percentage of survival after winter were recorded. Flowering data was noted according 2 criteria: 10 and $50 \%$ flowered plants per block. The third inflorescence of 10 plants per block was sampled in order to evaluate pod setting (percentage of flowers that set pods), number of seeds per pod and mean seed weight.

In 1993, the 25 populations were sown in small 2row plots $2.60 \mathrm{~m}$ long, $0.30 \mathrm{~m}$ apart, with 4 blocks. Two cutting managements were used in 1994, each on 2 blocks, one with frequent cuttings (dates of cuttings: $10 / 05,23 / 06,04 / 08,16 / 09,08 / 11)$, the other with normal cuttings (dates of cuttings: 24/05, 02/07, 19/08, 04/10). For each cutting, in each block and for each genotype, dry matter yield was evaluated. For the frequent and normal cutting regimes, 19 and 15 stand height measurements respectively were made between 13/03/1994 and 28/11/1994 during the successive regrowths.

Analyses of variance were performed for all recorded traits. The data were analysed by trial because all the populations were not represented in each trial and this reduced the possibilities of multivariate analysis. For the 1992 nursery, the effect of population and the effect of plants nested within population were tested. For the 1993 nursery, the block effect was added to the model. For the trial in small plots, the effects of population and block were tested, and the data recorded under the 2-cutting managements were considered as separate traits. Correlations between characters were computed on the mean values of the populations, and principal component analyses (PCA) were performed. The objective was to investigate the relationships between populations and to structure the variability in groups. Euclidian distances between populations were computed from their coordinates on the principal components, and an ascendant hierarchical clustering was carried out using the complete linkage method. The partition observed from the view of the tree was represented on the plan of the first 2 components. 


\section{RESULTS}

\section{Nursery 1992}

For all characters, the population effect was highly significant $(P<0.001)$. The effect of plants nested within population, tested against population effect, was not significant. PCA was computed with all the available traits. The first component accounted for $83.4 \%$ of the variation, the second component $11.3 \%$. The first component was positively correlated with plant height, stem length and yield. The second component was defined by diameter and percentage of rhizomatous plants. The tree based on Euclidian distances on principal components showed that 2 groups of populations can be defined; one group consisted of landraces or varieties of the ssp sativa (Maktar, Europe, Provence, Flamande and Marais de Luçon) and the tetraploid falcata population Krasnokutskaya, and the other group was the remaining populations, most of which were wild (fig 1). Sativa landraces and varieties were characterised by tall

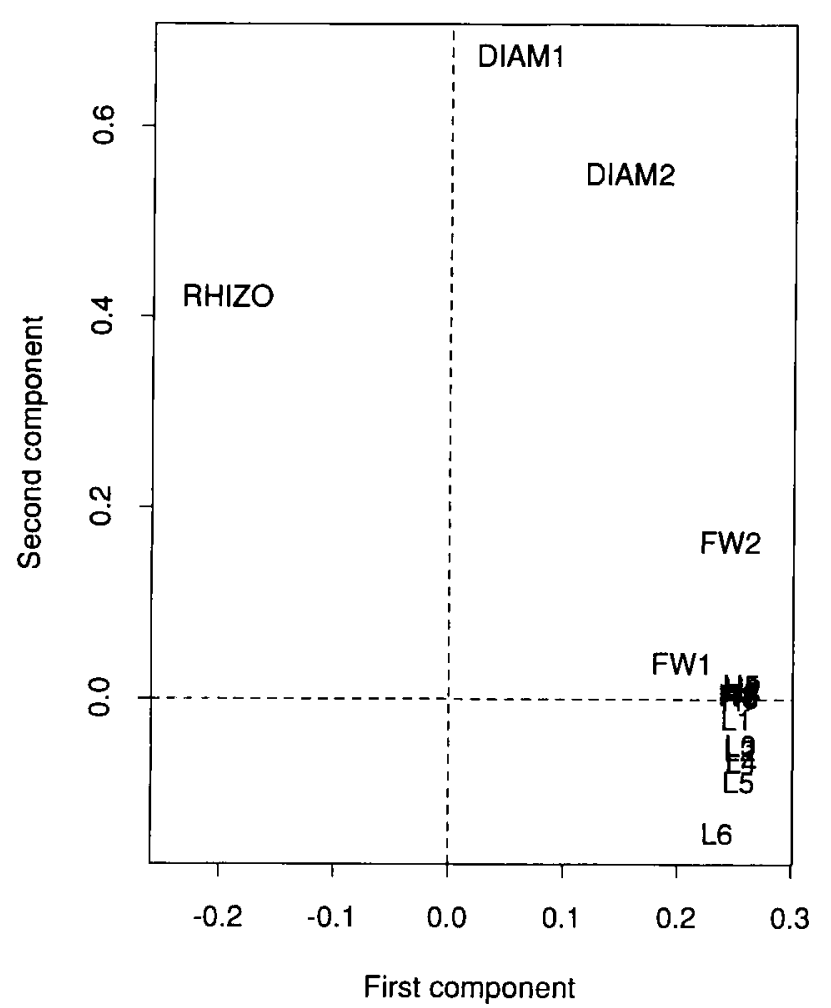

plants, long stems, high yields and no rhizomatous plants. The other populations, diploid or tetraploid falcata populations, the diploid sativa population, the diploid glomerata populations and tetraploid wild sativa populations Mielga, were characterised by lower plant height, stem length and yields (especially for the second cutting in August) and by the presence of rhizomatous plants (table II). However, in this last group, the populations showed large variation for plant diameter and percentage of rhizomatous plants. Diploid wild populations (coerulea, romanica and quasifalcata) had a low percentage of rhizomatous plants and a small plant diameter.

\section{Nursery 1993}

For all traits, the population effect was significant $(P<0.01)$, and the effect of block was either nonsignificant or lower than population effect.

With the characters available for all populations in 1993 and 1994 (flowering dates, plant diameter and rhizomatous trait were discarded as missing for either Gabès or glomerata). PCA

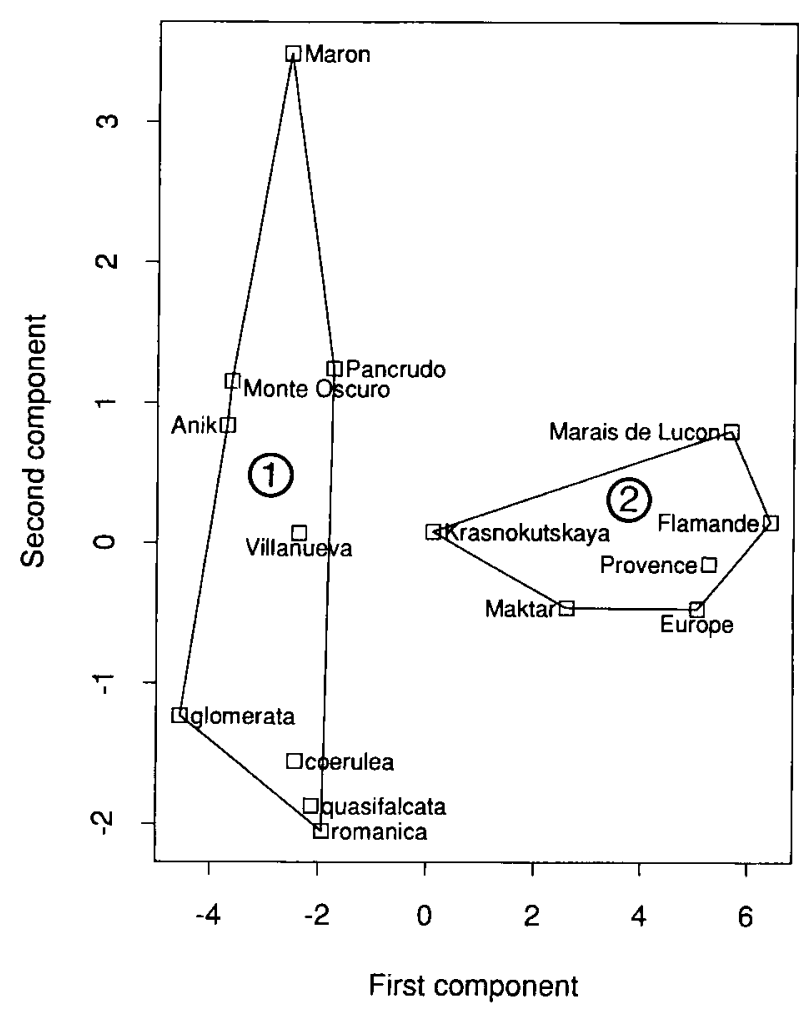

Fig 1. PCA diagram on the 1-2 plane of 15 populations studied in 1993 in the 1992 nursery. Left: diagram of the coefficients of correlation of the characters with the first 2 components; Right: diagram of the 15 populations. The characters considered were plant heights (H1-H6), stem lengths (L1-L6), plant diameters (DIAM1, DIAM2), \% rhizomatous plants (RHIZO), fresh weight per plant in 2 cuttings (FW1, FW2). 1 and 2 are the 2 groups shown by partition from Euclidian distances on the components of PCA. 
Table II. Main characteristics of the populations planted in 1992 in the nursery and studied in 1993 (SE: standard error).

\begin{tabular}{|c|c|c|c|c|c|c|c|}
\hline Population & Type a & $\begin{array}{c}\text { Diameter } \\
(\mathrm{cm}) \\
07 / 08 / 93\end{array}$ & $\begin{array}{l}\text { Plant height } \\
(\mathrm{cm}) \\
01 / 04 / 93\end{array}$ & $\begin{array}{c}\text { Stem length } \\
(\mathrm{cm}) \\
07 / 05 / 93\end{array}$ & $\begin{array}{c}\% \\
\text { rhizomatous } \\
\text { plants }\end{array}$ & $\begin{array}{c}\text { Plant fresh } \\
\text { cutting } \\
28 / 06 / 93\end{array}$ & $\begin{array}{c}\text { Yield } \\
\text { cutting } \\
10 / 08 / 93\end{array}$ \\
\hline Flamande & C $4 x$ & 44.2 & 27.3 & 64.2 & 0.00 & 1.672 & 0.791 \\
\hline Europe & C $4 x$ & 38.6 & 23.8 & 60.7 & 0.00 & 1.419 & 0.659 \\
\hline Provence & C $4 x$ & 40.2 & 24.5 & 60.6 & 0.00 & 1.386 & 0.824 \\
\hline Maktar & C $4 x$ & 35.9 & 17.3 & 50.1 & 0.00 & 1.003 & 0.648 \\
\hline Marais de Luçon & $C 4 x$ & 47.7 & 25.9 & 59.2 & 0.00 & 1.950 & 0.771 \\
\hline Villanueva & W $4 x$ & 32.7 & 4.1 & 31.5 & 51.22 & 0.974 & 0.243 \\
\hline Monte Oscuro & W $4 x$ & 37.6 & 2.0 & 29.4 & 74.29 & 0.713 & 0.083 \\
\hline Pancrudo & $W 4 x$ & 40.6 & 5.6 & 31.8 & 56.76 & 1.106 & 0.345 \\
\hline coerulea & $W 2 x$ & 23.6 & 6.5 & 31.2 & 23.40 & 0.936 & 0.053 \\
\hline Maron & $W 4 x$ & 46.8 & 4.7 & 27.3 & 91.30 & 1.153 & 0.382 \\
\hline Krasnokutskaya & W $4 x$ & 35.3 & 10.7 & 39.9 & 35.71 & 1.313 & 0.453 \\
\hline Anik & $C 2 x$ & 31.8 & 3.1 & 25.6 & 77.50 & 0.821 & 0.173 \\
\hline romanica & $W 2 x$ & 23.7 & 4.3 & 36.9 & 10.20 & 1.273 & 0.147 \\
\hline quasifalcata & $W 2 x$ & 24.3 & 4.8 & 33.1 & 4.08 & 1.383 & 0.149 \\
\hline glomerata & $W 2 x$ & 21.7 & 0 & 25.5 & 62.50 & 0.363 & 0.031 \\
\hline Mean & & 34.33 & 10.97 & 40.5 & 32.46 & 1.164 & 0.384 \\
\hline SE & & 12.05 & 5.12 & 7.25 & 41.96 & - & \\
\hline
\end{tabular}

a C: cultivated; W: wild; 4 x: tetraploid; 2 x: diploid.

gave 2 components accounting for 72.5 and $11.7 \%$ of variation respectively. The first component was explained by regrowth scores, growth habit, stem size, leaf size, inflorescence shape, plant height, number of seeds per pod and mean seed weight. The second component was explained by winter survival (fig 2). The Euclidian distances isolated the group of sativa landraces and varieties from the remaining populations by their higher regrowth scores and their higher plants. The Ukrainian population Krasnokutskaya was intermediate between these 2 groups, and glomerata had lower regrowth scores and plant heights than the other wild populations (table III). Some landraces from the south of the Mediterranean (Gabès, D15, Pool5) had a lower winter survival than French landraces and populations (Flamande, Europe, Marais de Luçon, Provence and Magali) (table III). In this diagram, among the wild populations, the sativa Mielga cannot be distinguished from the others. The distinction between Mielga and other wild populations was obvious considering flower colour (table III); Mielga populations and coerulea, as the other sativa populations, had purple flowers, whereas falcata populations had yellow flowers. Pod set showed a wide variation; wild diploid (coerulea, romanica and quasifalcata) and Mielga (Villanueva, Monte Oscuro and Pancrudo) populations had lower pod sets than the remaining ones (table III). Within the wild populations, the diploid populations had smaller seeds than the tetraploid populations (on average, mean seed weight was $1.34( \pm 0.32) \mathrm{mg}$ for diploid populations, and $1.71( \pm 0.27) \mathrm{mg}$ for tetraploid wild populations). French landraces and varieties flowered earlier than the other populations (table III). Flowering dates of coerulea, romanica and quasifalcata were late.

\section{Small plots 1993}

The population effect was significant for the stand heights and yields per cutting.

A PCA was computed on the measurements of stand heights ( 19 and 17 measurements in frequent and normal cutting regimes, respectively), and on the yield evaluation per cutting and on the total (5 cuttings in the frequent regime; 4 cuttings in the normal regime). The first component explained $81.1 \%$ of the variation, the second component $14.2 \%$. All height measurements and 

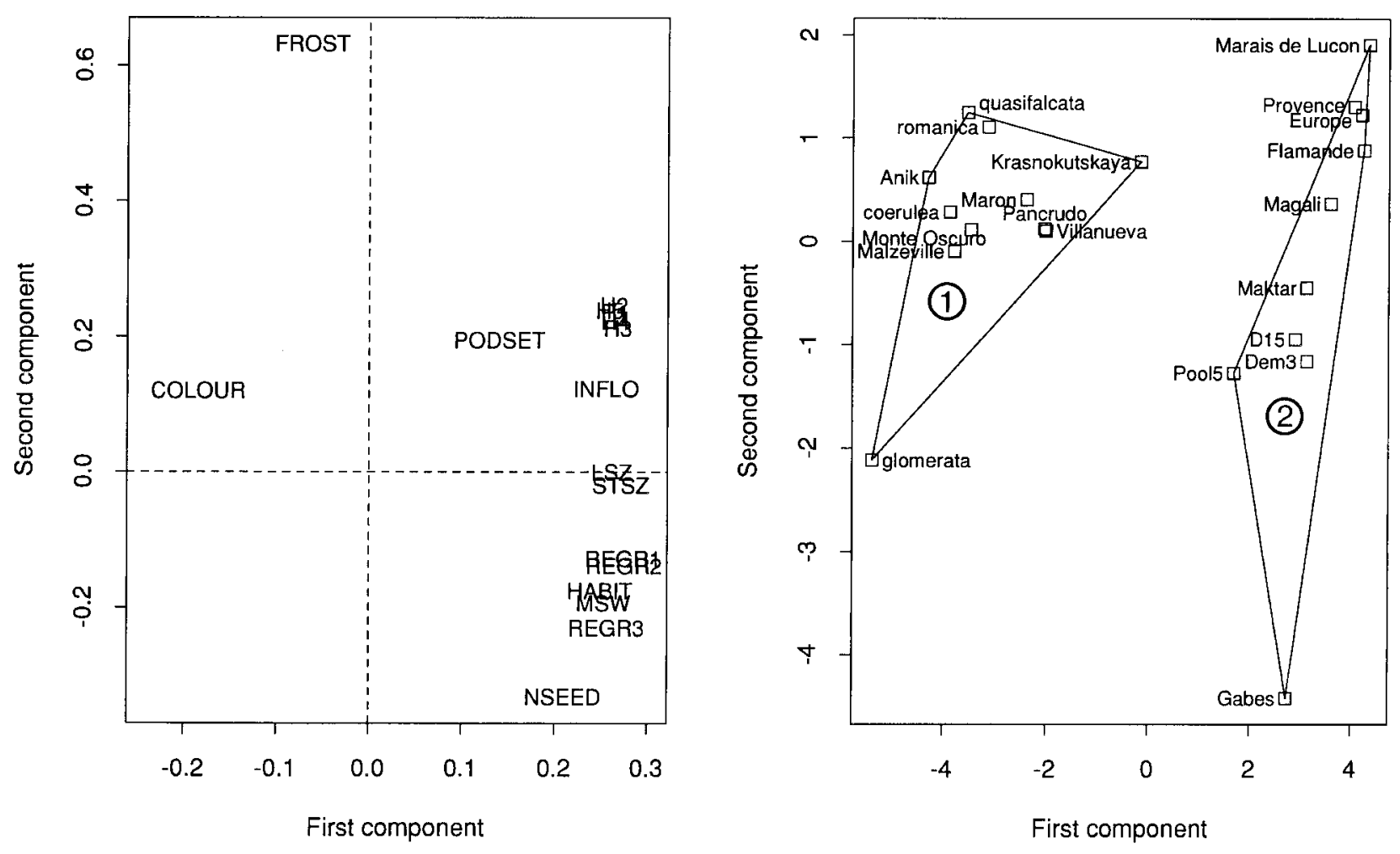

Fig 2. PCA diagram on the 1-2 plane of 21 populations studied in 1993 and 1994 in the 1993 nursery. Left: diagram of the coefficients of correlation of the characters with the first 2 components; Right: diagram of the 21 populations. The characters considered were growth habit (HABIT), regrowth scores (REGR1 to REGR3), stem size (STSZ), leaf size (LSZ), inflorescence shape (INFLO), plant heights ( $\mathrm{H} 1-\mathrm{H} 5)$, number of seeds per pod (NSEED), mean 1000 seed weight (MSW), frost damage (FROST), pod set (PODSET), flower colour (COLOUR). 1 and 2 are the 2 groups shown by partition from Euclidian distances on the components of PCA.

yields per cutting except on the first cutting contributed to the first component. The second component was correlated positively to yield of the first cutting in both regimes, and negatively to yield of autumn cutting. Two main groups appeared with the Euclidian distances (fig 3), one with the cultivated sativa populations or varieties that were high yielding and tall, the other with the wild populations (falcata, sativa Mielga and coerulea, and glomerata) that were lower yielding and shorter (table IV). Within the cultivated populations, the French populations adapted to a cool climate were separated from the Mediterranean populations because of their higher yield in the first cutting and lower relative yield in autumn. The glomerata population was close to the group of wild populations, but with the lowest yield and weak growth, and a low yield in first cutting. In autumn, forage yield was low for all the wild populations (table IV). For the cultivated populations, yield and stand height in autumn were similar for north European populations and for Mediterranean populations, but the proportion of yield produced in autumn over the annual yield was higher for the Mediterranean populations than for the others.

\section{DISCUSSION}

Whatever the morphological and agronomic traits used to describe the populations, 2 main groups of populations were separated. The 3 trials gave consistent information on the populations studied. The first group contained the French, Spanish and North African varieties and populations. They were characterised by high yields, tall plants, erect growth habit, good regrowth after cutting, and high mean seed weight. The French populations (Europe, Flamande and Marais de Luçon) yielded more in the moderately cool climate of Lusignan than the Mediterranean climates (Provence, Magali, Dem3, Pool5, D15, Gabès, Tierra de Campos, Ampurdan, Mediterraneo and Aragon), and had purple flowers variegated with yellow instead of pure purple. A large proportion of annual forage yield was pro- 
Table III. Main characteristics of the populations planted in 1993 in the nursery and studied in 1993 and 1994.

\begin{tabular}{|c|c|c|c|c|c|c|c|c|c|}
\hline Population & Type & $\begin{array}{l}\text { Regrowth } \\
\text { score }^{a}\end{array}$ & $\begin{array}{l}\text { Growth } \\
\text { habit b }\end{array}$ & $\begin{array}{c}\text { Winter } \\
\text { survivalc }\end{array}$ & $\begin{array}{l}\text { Plant height } \\
(\mathrm{cm})^{\mathrm{d}}\end{array}$ & $\begin{array}{c}\text { Flowering } \\
\text { date }^{e}\end{array}$ & $\begin{array}{l}\text { Flower } \\
\text { colour }\end{array}$ & $\begin{array}{c}\text { Mean seed } \\
\text { weight (mg) }\end{array}$ & Pod set \\
\hline Flamande & C $4 x$ & 3.83 & 3.00 & 96.3 & 46.8 & 2 & 1.15 & 2.33 & 48.33 \\
\hline Europe & C $4 x$ & 3.33 & 2.93 & 100 & 47.7 & 3 & 1.05 & 2.36 & 60.43 \\
\hline Provence & C $4 x$ & 3.67 & 3.00 & 100 & 46.3 & 7 & 1.16 & 2.24 & 55.97 \\
\hline Marais de Luçon & C $4 x$ & 3.33 & 3.00 & 100 & 53.8 & 7 & 1.19 & 2.23 & 52.03 \\
\hline Magali & C $4 x$ & 3.50 & 3.00 & 100 & 43.7 & 6 & 1.07 & 2.54 & 46.67 \\
\hline D15 & C $4 x$ & 3.67 & 3.00 & 83.9 & 37.9 & 13 & 1.13 & 2.19 & 36.90 \\
\hline Dem3 & C $4 x$ & 4.17 & 3.00 & 91.2 & 31.8 & 13 & 1.06 & 2.59 & 51.30 \\
\hline Pool 5 & C $4 x$ & 3.17 & 3.00 & 78.6 & 30.4 & 11 & 1.02 & 2.29 & 48.60 \\
\hline Gabès & C $4 x$ & 3.83 & 3.00 & 32.1 & 26.7 & - & 1.00 & 2.53 & 47.50 \\
\hline Maktar & C $4 x$ & 4.00 & 3.00 & 92.7 & 38.7 & 8 & 1.05 & 2.38 & 44.10 \\
\hline Villanueva & $W 4 x$ & 1.83 & 2.07 & 100 & 22.7 & 10 & 1.16 & 1.73 & 37.67 \\
\hline Monte Oscuro & $W 4 x$ & 1.17 & 1.32 & 100 & 21.0 & 13 & 1.00 & 1.53 & 26.80 \\
\hline Pancrudo & $W 4 x$ & 1.67 & 1.91 & 100 & 23.7 & 5 & 1.00 & 1.60 & 29.47 \\
\hline coerulea & $W 2 x$ & 1.33 & 1.32 & 100 & 16.5 & 25 & 1.00 & 0.89 & 43.73 \\
\hline Maron & $W 4 x$ & 1.00 & 1.21 & 98.2 & 18.0 & 8 & 2.91 & 1.63 & 56.00 \\
\hline Malzeville & $W 4 x$ & 1.50 & 1.21 & 100 & 12.0 & 11 & 2.93 & 1.56 & 53.77 \\
\hline Krasnokutskaya & $W 4 x$ & 1.50 & 2.51 & 98.2 & 29.7 & 10 & 2.92 & 2.20 & 53.00 \\
\hline Anik & $C 2 x$ & 2.33 & 1.24 & 100 & 11.2 & 15 & 3.00 & 1.43 & 52.47 \\
\hline romanica & $W 2 x$ & 1.33 & 1.78 & 100 & 20.5 & 19 & 3.00 & 1.34 & 40.57 \\
\hline quasifalcata & $W 2 x$ & 1.17 & 1.38 & 100 & 18.8 & 22 & 3.00 & 1.34 & 36.87 \\
\hline glomerata & $W 2 x$ & 1.00 & 2.52 & 81.8 & 5.3 & - & 3.00 & 1.72 & 21.10 \\
\hline Mean & & 2.49 & 2.31 & 92.9 & 28.7 & 11 & 1.70 & 1.90 & 44.86 \\
\hline SE & & 0.39 & 0.17 & 15.4 & 3.21 & 3.2 & 0.08 & 0.19 & 9.65 \\
\hline
\end{tabular}

a Score from 1 (no regrowth) to 5 (strong regrowth) (06/10/1993); b score from 1 (prostrate) to 3 (erect) (02/09/1993); c \% of surviving plants after winter (07/03/1994); d measured on 02/05/1994; e measured when $10 \%$ of the plants had one open flower, in days after 18/05/1994; ' score: 1 (purple), 2 (variegated), and 3 (yellow).

duced in autumn in the Mediterranean populations, and this feature confirms the regrowth capacity of Mediterranean types in autumn compared to northern European types and wild populations.

The second group contained wild falcata (Maron, Malzeville, romanica, quasifalcata and Krasnokustkaya) and wild sativa (coerulea, Monte Oscuro, Villanueva and Pancrudo) populations including the falcata Canadian variety Anik, and were characterised by reduced growth, low forage yields, prostrate growth habit, low mean seed weight. Their yield in autumn was low or zero. The glomerata population was close to this group. Kranokutskaya tended to be intermediate between the main 2 groups because it had better regrowth scores and higher yields than the other falcata populations. The Mielga populations, known as wild sativa, could not be distinguished morphologically and agronomically from the falcata populations, except by flower colour, purple for Mielga, yellow for falcata. The wild Mielga populations were clearly different from cultivated populations, as that were already shown by Delgado Enguita (1989) and Prosperi et al (1993). They could represent the wild populations that were already present in Spain when the cultivated forms were introduced by the Arabs in the 8th Century (Delgado Enguita, 1989). The differences between wild Spanish populations and cultivated ones show the progress made by man in domesticating lucerne. The main improvements related to a more erect growth habit, adapted to forage harvesting, regrowth and forage yield, but also pod set and mean seed weight. It seems that very few crosses occurred between Mielga and cultivated landraces, even though they are sympatric (Prosperi et al, 1990). This might be the consequence of the crop management of the landraces, often irrigated, and harvested before flowering. A large range of flowering dates was observed. Response to temperature and photo- 
Table IV. Total yield in 1994 (t/ha), yield and stand height $(\mathrm{cm})$ in the first cutting in spring (10/05), yield and stand height in the last cutting in autumn (08/11) in frequent cutting regime of the small plot trial sown in 1993.

\begin{tabular}{|c|c|c|c|c|c|c|}
\hline Population & Type & $\begin{array}{c}\text { Total yield } \\
\text { (t/ha) }\end{array}$ & $\begin{array}{l}\text { Yield of spring } \\
\text { cutting (t/ha) }\end{array}$ & $\begin{array}{l}\text { Height at spring } \\
\text { cutting }(\mathrm{cm})\end{array}$ & $\begin{array}{c}\text { Yield of autumn } \\
\text { cutting (t/ha) }\end{array}$ & $\begin{array}{c}\text { Height at autumn } \\
\text { cutting }(\mathrm{cm})\end{array}$ \\
\hline Flamande & C $4 x$ & 21.04 & 6.57 & 93.75 & 1.81 & 45.50 \\
\hline Europe & C $4 x$ & 19.94 & 7.57 & 92.15 & 1.50 & 44.00 \\
\hline Provence & C $4 x$ & 16.11 & 4.89 & 86.25 & 1.62 & 46.75 \\
\hline Marais de Luçon & C $4 x$ & 17.11 & 6.23 & 88.75 & 1.25 & 37.50 \\
\hline Magali & C $4 x$ & 18.44 & 5.45 & 81.25 & 1.86 & 43.75 \\
\hline D15 & $C 4 x$ & 16.38 & 4.61 & 75.00 & 1.71 & 51.75 \\
\hline Dem3 & C $4 x$ & 10.80 & 2.24 & 60.00 & 1.66 & 49.75 \\
\hline Pool 5 & C $4 x$ & 10.55 & 2.80 & 56.25 & 1.34 & 49.25 \\
\hline Gabès & C $4 x$ & 5.56 & 1.08 & 52.50 & 0.81 & 52.00 \\
\hline Maktar & C $4 x$ & 15.60 & 4.41 & 78.75 & 1.58 & 48.25 \\
\hline Aragon & C $4 x$ & 11.96 & 2.77 & 77.50 & 1.55 & 49.25 \\
\hline Mediterraneo & C $4 x$ & 10.26 & 2.85 & 68.75 & 1.13 & 46.50 \\
\hline Tierra de Campos & $C 4 x$ & 13.98 & 3.68 & 80.00 & 1.30 & 43.75 \\
\hline Ampurdan & $C 4 x$ & 10.90 & 3.09 & 65.00 & 1.56 & 40.50 \\
\hline Villanueva & W $4 x$ & 7.67 & 2.98 & 58.75 & 0.00 & 7.25 \\
\hline Monte Oscuro & W $4 x$ & 4.97 & 2.65 & 50.00 & 0.00 & 1.75 \\
\hline Pancrudo & W $4 x$ & 6.50 & 3.13 & 55.00 & 0.00 & 2.50 \\
\hline coerulea & $W 2 x$ & 5.84 & 3.50 & 57.50 & 0.00 & 1.50 \\
\hline Maron & W $4 x$ & 11.08 & 5.15 & 63.75 & 0.05 & 6.25 \\
\hline Malzeville & W $4 x$ & 9.52 & 3.94 & 62.50 & 0.06 & 8.00 \\
\hline Krasnokutskaya & $W 4 x$ & 12.28 & 6.08 & 67.50 & 0.00 & 8.25 \\
\hline Anik & $C 2 x$ & 5.12 & 2.64 & 43.75 & 0.00 & 1.00 \\
\hline romanica & $W 2 x$ & 6.84 & 4.03 & 58.75 & 0.00 & 4.25 \\
\hline quasifalcata & $W 2 x$ & 6.52 & 4.15 & 53.75 & 0.00 & 4.50 \\
\hline glomerata & $W 2 x$ & 0.30 & 0.28 & 31.25 & 0.00 & 1.75 \\
\hline Mean & & 11.01 & 3.87 & 66.30 & 0.83 & 27.82 \\
\hline SE & & 1.79 & 0.77 & 6.93 & 0.19 & 3.35 \\
\hline
\end{tabular}

period of each genotype could be involved in flowering (Guy et al, 1971).

The variegated flower colour of the French populations provides evidence for the genetic introgression of falcata types in these sativa populations. The crosses between sativa and falcata should have occurred in northern and eastern France and Europe where both sub-species coexist (Lesins and Lesins, 1979). The falcata trait useful for adaptation of lucerne to the northern climates of Europe was their winter resistance associated with a reduced growth during cold periods.

The convergent evolution of forms between wild falcata and wild sativa Mielga probably shows the strong advantages of the prostrate growth habit, weak and slow growth for adaptation and persistence in nature. Thanks to this morphology, the vegetative buds escape animal grazing and the plants resist animal treading. The prostrate growth habit and rhizomatous trait were shown to contribute to tolerance to grazing (Prosperi et al, 1993), so that the wild tetraploid populations with these traits could be used in crosses with elite cultivars to improve their persistence under grazing.

Within the wild types, no distinction was obvious between diploid and tetraploid populations. The romanica and quasifalcata populations $(2 \mathrm{x})$ are not different from Maron, Malzeville and Krasnokutskaya $(4 \mathrm{x})$, and coerulea $(2 \mathrm{x})$ are not different from Mielga $(4 \mathrm{x})$. Only mean seed weight was higher on wild tetraploids than on wild diploids. The theoretical advantage of tetraploid forms on diploid ones for growth, yield and development was inapparent. Furthermore, ploidy level is considered as a barrier against interbreeding, thus allowing divergent evolution (Lesins and Lesins, 1979). This genetic isolation between diploid and tetraploid had no conse- 


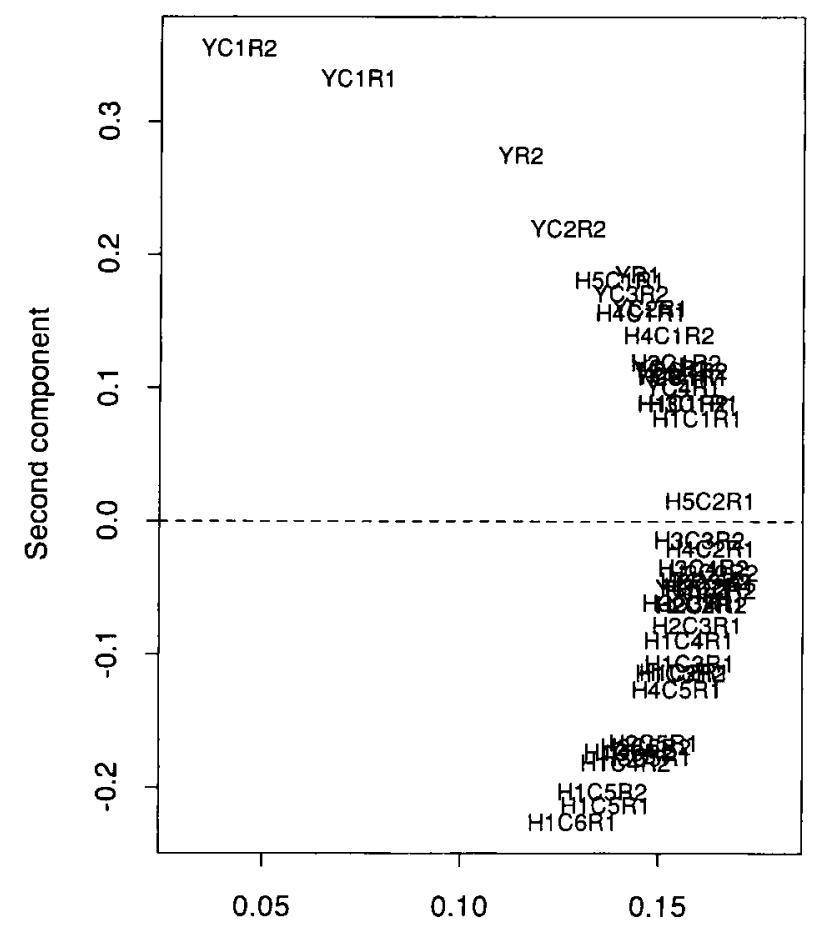

First component

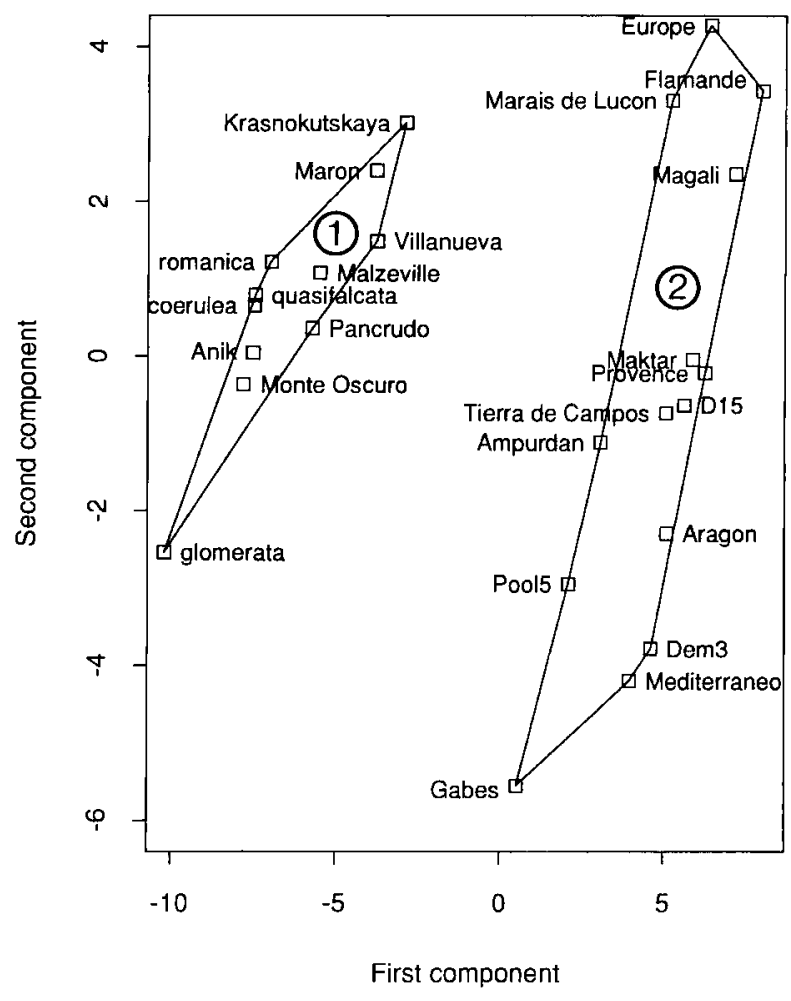

Fig 3. PCA diagram on the 1-2 plane of 25 populations studied in 1994 in the 1993 small plot trial. Left: diagram of the coefficients of correlation of the characters with the first 2 components; Right: diagram of the 25 populations. The characters considered were the measurements of plants heights $(\mathrm{H} 1-\mathrm{H} 6)$ per regrowth cycle $(\mathrm{C} 1-\mathrm{C} 6)$ in the 2 cutting regimes $(\mathrm{R} 1, \mathrm{R} 2)$ and yields per cutting $(\mathrm{Y})$ in the 2 cutting regimes. 1 and 2 are the 2 groups shown by partition from Euclidian distances on the components of PCA.

quence on the morphological traits studied here. However, the fact that cultivated lucernes are tetraploid proves the higher potentialities of certain tetraploid populations.

\section{ACKNOWLEDGMENT}

This study was supported by the Programme Prodige of INRA.

\section{REFERENCES}

Birouk A, Guy P (1986) Partition de populations marocaines de luzerne locale en vue de leur conservation en réservoir massal. In: Distance, divergence et variabilité génétique, Séminaire du département de génétique et d'amélioration des plantes, Méribel 11 15 mars 1986, INRA, Paris, France, 196-203

Birouk A, Dattee Y, Sadiki M, Roumet P (1989) Évaluation agronomique et adaptation de populations marocaines de luzerne (Medicago sativa $\mathrm{L}$ ). agronomie 9, 363-376

Bolton JL, Goplen BP, Baenziger H (1972) World distribution and historical developments. In: Alfalfa
Science and Technology ( $\mathrm{CH}$ Hanson, ed), ASA Publishers, Agronomy (Madison) 15, 1-34

Delgado Enguita I (1989) Estudio de la variabilidad de las Mielgas aragonesas en areas de precipitacion anual inferior a $600 \mathrm{~mm}$. Thesis doctoral, Escuela Technica Superior de Ingeniero Agronomos, Universidad Politecnica de Madrid, Spain, $168 \mathrm{p}$

Dunbier MW, Eskew DL, Bingham ET, Schrader LE (1975) Performance of genetically comparable diploid and tetraploid alfalfa: agronomic and physiological parameters. Crop Sci 15, 211-214

Guy P, Blondon F, Durand J (1971) Action de la température et de la durée d'éclairement sur la croissance et la floraison de 2 types éloignés de luzerne cultivée, Medicago sativa L. Ann Amélior Plant 21, 409-422

Heinrichs DH (1963) Creeping alfalfas. Adv Agron 15 317-337

Hidalgo Maynar F (1966) Clasificatión de las alfalfas españolas. Association de Investigation para la mejora de la alfalfa, Zaragoza, Spain, $86 \mathrm{p}$

Lesins KA, Lesins I (1979) Genus Medicago (Leguminosae) A taxonomic study. Junk bv Publishers, The Hague, The Netherlands, $228 p$

Prosperi JM, Angevain M, Mansat P (1990) Valorization of forage genetic resources for selection of adapted cultivars. Example of wild 
Mediterranean lucernes. 6th Meeting FAO on Mediterranean Pastures and Fodder Crops, Bari, 95-98

Prosperi JM, Angevain M, Génier G, Olivieri I, Mansat $P$ (1993) Sélection de nouvelles légumineuses fourragères pour les zones difficiles méditerranéennes. Fourrages 135, 343-354
Quiros CF, Bauchan GR (1988) The genus Medicago and the origin of the Medicago sativa complex. In: Alfalfa and Alfalfa Improvement (AA Hanson, ed), ASA-CSSA-SSSA Publishers, Agronomy (Madison) 29, 93-124

Volenec JJ (1988) Herbage growth and carbohydrate metabolism of diploid and tetraploid alfalfa. Crop Sci 28, 128-132 